\title{
EKSTERNALITAS MODEL ECO-SETTLEMENTS DI DAERAH ALIRAN SUNGAI (DAS) HULU CIMANUK (STUDI KASUS KAMPUNG MUARA, DESA SUKAWARGI, KECAMATAN CISURUPAN,KABUPATEN GARUT, JAWA BARAT)
}

\author{
Deddy Ma'mun dan Noresya Ezmira
}

\author{
Staf Pengajar Program Studi Agribisnis Fakultas Pertanian \\ Universitas Padjadjaran
}

\begin{abstract}
Kampung Muara which is the upstream of Cimanuk watershed is one of the areas experiencing environmental degradation caused by land use. In response to these problems, the Research Institute for Human Settlements devised a model of eco-settlements as an upstream of watershed development. This research aims to determine the externalities rised from the implementation of eco-settlements model. The technique used for this research is case study, while design used is a descriptive method that is supported by primary and secondary data. The result of this research shows that, the implementation of eco-settlements model can provide external economy and lead to external diseconomy. External economy generated from tangible benefit and intangible benefit. Tangilble benefits received by the community improvement of water quality and additional income for the community. Intangible benefits gained from the implementation of eco-settlements model is the presence of erosion control, reduce risk of flooding, the formation of informal institution Pokjamas Hikmatul Jama'ah, and knowledge improvement of the training process, particularly in the operation of the technology. External diseconomy of the implementation eco-settlements model is the emergence of dependence on government support.
\end{abstract}

Keyword: External Economy and Extenal Diseconomy, Eco-settlements, Watershed. 


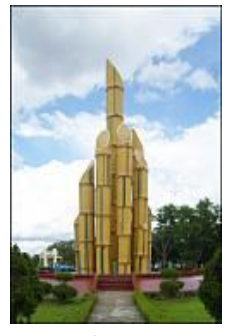

Ma'mun dan Ezmira,

Eksternalitas Model Eco

settlements di DAS...

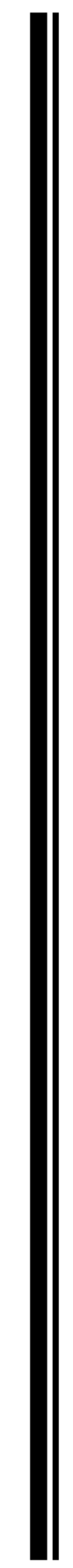




\section{PENDAHULUAN}

Pertambahan jumlah penduduk yang terus meningkat menjadi penyebab dari tingginya tekanan penduduk terhadap daya dukung lahan. Oleh karena itu, masyarakat memanfaatkan sumber daya alam dan memanfaatkan lahan sebagai permukiman. Pemanfaatan sumber daya alam dan lahan yang tidak mempertimbangkan aspek kelestarian lingkungan dapat menimbulkan eksternalitas negatif, yaitu terjadi gangguan lingkungan daerah aliran sungai (DAS) hulu. Berkurangnya keseimbangan lingkungan diindikasikan melalui adanya banjir, erosi, longsor, dan degradasi lahan.

Menanggapi permasalahan tersebut, Pusat Penelitian dan Pengembangan Permukiman (Puslitbangkim) merancang suatu pola pengelolaan DAS hulu yang berwawasan lingkungan, yaitu melalui model eco-settlements. Eco-settlements di hulu DAS diartikan sebagai permukiman yang mampu menjaga kelestarian hulu DAS, dengan memperhatikan harmonisasi tiga pilar keberlanjutan (ekologi, sosial, dan ekonomi) serta didukung oleh sistem kelembagaan yang kapabel (Puslitbangkim, 2010). Maksud dari ketiga pilar tersebut adalah secara sosial dapat diterima oleh masyarakat, secara ekologi dipertanggungjawabkan, dan secara ekonomi dapat memberikan keuntungan bagi setiap pihak yang terlibat.

Pengembangan model ecosettlements dilakukan secara bertahap sejak tahun 2008 hingga tahun 2012. Setiap pelaksanaan program akan memberikan eksternalitas positif (External Economy, EE) dan menimbulkan kesternalitas negatif (External Diseconomy, ED). Fauzi (2004) dalam Wikarta (2010) menjelaskan bahwa eksternalitas adalah dampak (positif atau negatif) atau dalam bahasa ekonominya disebut net cost atau benefit, dari tindakan satu pihak terhadap pihak lain. Secara lebih spesifik, eksternalitas terjadi jika kegiatan produksi atau konsumsi dari satu pihak mempengaruhi utilitas (kegunaan) pihak lain secara tidak diinginkan, dan pihak pembuat eksternalitas tidak menyediakan kompensasi terhadap pihak yang terkena dampak. Maka dari itu, diperlukan suatu analisis yang mengkaji eksternalitas pengembangan DAS hulu model eco-settlements di DAS hulu Cimanuk.

\section{METODE PENELITIAN}

Penelitian dilakukan pada tim pelaksana Puslitbangkim, masyarakat, dan petani di hulu DAS Cimanuk, yaitu Kampung Muara, Desa Sukawargi, Pertanian, Volume 1 Nomor 1, April 2012 Kecamatan Cisurupan, 


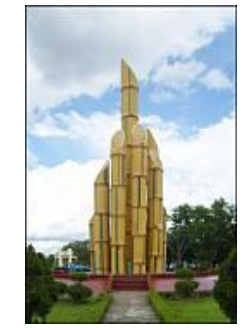

Ma'mun dan Ezmira, Eksternalitas Model Eco settlements di DAS...)
Kabupaten Garut, Jawa Barat. Tempat penelitian dipilih secara sengaja (purposive) dengan pertimbangan bahwa lokasi tersebut merupakan lokasi percontohan model pengelolaan DAS secara terpadu dalam pembinaan Kementrian Pekerjaan Umum Puslitbangkim. Teknik penelitian yang digunakan adalah studi kasus dan desain penelitian yang digunakan adalah metode deskriptif yang didukung oleh data primer dan sekunder. Data primer diperoleh dari pengamatan partisipatif dan wawancara kepada informan kunci (key informan), sedangkan data sekunder diperoleh malalui telaah dokumen. Wawancara dilakukan kepada koordinator tim pelaksana Puslitbangkim, masyarakat, dan petani di Kampung Muara.

\section{HASIL DAN PEMBAHASAN}

\section{Implementasi Model Eco- settlements}

Pengembangan DAS hulu model eco-settlements diimplementasikan melalui beberapa kegiatan sesuai dengan pilar-pilar yang membangunnya. Pilar sosial diimplementasikan melalui pemberdayaan masyarakat, pilar ekologi diimplementasikan melalui penataan permukiman dan usahatani konservasi agroforestri, dan pilar ekonomi diimplementasikan melalui upaya peningkatan pendapatan masyarakat melalui pembelian bahan sumber daya lokal, pemberian upah pembangunan, dan pemberian upah usahatani.

\section{Pilar Sosial}

Sejak tahun 2008 hingga 2009 dilakukan sosialisasi kepada pemerintah daerah dan masyarakat. Sosialisasi kepada masyarakat dilakukan melalui forum, namum pada pelaksanaannya masyarakat belum mampu menyampaikan aspirasi secara terbuka. Sesuai dengan lima program utama dalam pemberdayaan, maka implementasi aspek sosial dalam model eco-settlements adalah sebagai berikut:

\section{Penyadaran}

Penyadaran merupakan proses dimana masyarakat mengetahui potensi diri dan potensi sumber daya alam desa. Proses ini dilakukan melalui identifikasi kebutuhan, penentuan/penyepakatan lokasi, dan perancangan. Identifikasi kebutuhan dilaksanakan secara partisipatif dengan melibatkan masyarakat melalui Survei Kampung Sendiri (SKS) dan rembug warga untuk menyepakati prioritas kebutuhan.

Setelah terbentuk prioritas kebutuhan, selanjutnya dilakukan penentuan/penyepakatan lokasi. Kegiatan yang dilakukan adalah penyiapan lahan untuk pembangunan sarana prasarana, 
dimana lahan yang digunakan adalah lahan hibah dari masyarakat. Adanya peran serta masyarakat dalam penyediaan lahan merupakan bentuk swadaya dan partisipasi masyarakat dalam implementasi model eco-settlements. Selain penyepakatan lahan untuk sarana dan prasarana, dilakukan juga penyepakatan masyarakat penerima pembangunan atau perbaikan rumah sebagai percontohan rumah layak huni dan sehat. Penerima bantuan merupakan masyarakat yang kondisi fisik rumahnya sudah rusak namun tidak mampu untuk memperbaikinya.

\section{Pengorganisasian}

Pengorganisasian

merupakan pembentukan organisasi oleh masyarakat dimana tim pelaksana Puslitbangkim berperan sebagai fasilitator. Organisasi yang dibentuk adalah organisasi informal Kelompok Kerja Masyarakat (Pokjamas) Hikmatul Jama'ah yang berfungsi sebagai media komunikasi antar masyarakat dalam pelaksanaan model. Kepengurusan Pokjamas terdiri dari lima pengurus inti dan 20 orang anggota.

\section{Kaderisasi Pendampingan Kaderisasi pendampingan yaitu mempersiapkan masyarakat untuk melanjutkan pemeliharaan dan pengembangan potensi atau kegiatan secara swadaya dan}

mandiri. Proses ini diimplementasikan melalui pembekalan, bimbingan, dan pendampingan yang dilakukukan berdasarkan azas TRIDAYA, yaitu sosial kemasyarakatan, usaha ekonomi lokal, dan pendayagunaan sarana prasarana. Dalam mendukung keberlanjutan model eco-settlements secara mandiri, maka dilakukan pembekalan pengetahuan dan pengelolaan teknologi melalui pelatihan.

\section{Dukungan Teknis}

Adanya dukungan dari institusi yang kompeten bertujuan untuk mempercepat proses adopsi dan adaptasi teknologi dan sistem. Tim pelaksana Puslitbangkim terdiri dari sumber daya manusia yang kompeten dalam menangani setiap aspek model ecosettlements.

\section{Pengelolaan Sistem}

Dalam pelaksanaan model eco-settlements, Puslitbangkim bekerja sama dengan institusi lain, diantaranya lembaga penelitian, lembaga pendidikan, dan pemerintah daerah setempat. Proses monitoring dan evaluasi di lapangan dilakukan oleh Pokjamas sebagai lembaga informal di lokasi studi.

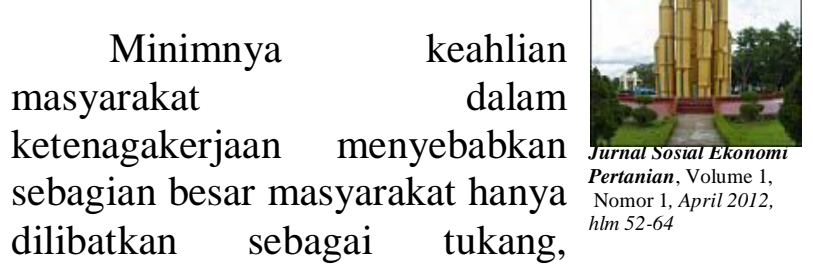




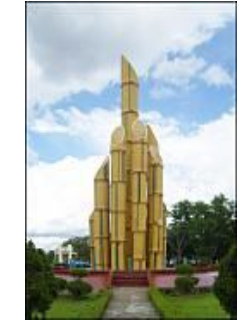

Ma'mun dan Ezmira, Eksternalitas Model Eco settlements di DAS...)

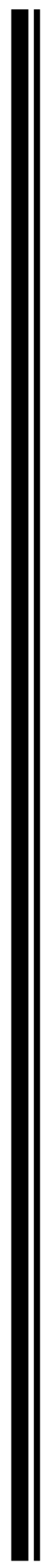

sedangkan untuk pekerja ahli sebagian besar berasal dari kontraktor. Dalam pelaksanaan usahatani konservasi agroforestri, masyarakat akan dilibatkan sebagai buruh tani dan penguji tingkat erosi tanah yang diukur dari sampel tanah dalam bak penampung.

\section{Pilar Ekologi}

Aspek ekologi merupakan pilar penting pengembangan DAS hulu terutama dalam mengembalikan fungsinya sebagai area tangkapan air (catchment area). Adanya permukiman serta aktivitas masyarakat yang kurang sadar akan kelestarian lingkungan menyebabkan lokasi penelitian termasuk dalam kondisi cemar berat. Peningkatan kualitas ekologi diwujudkan dengan cara perbaikan kondisi permukiman, peningkatan kualitas dan kuantitas air, peningkatan kualitas tanah, peningkatan kualitas udara, serta perbaikan tata guna lahan.

Penataan permukiman bertujuan untuk memperbaiki kondisi permukiman yang belum sesuai dengan fungsi yang seharusnya, yaitu sebagai kawasan konservasi. Upaya yang dilakukan adalah dengan memperbaiki kondisi rumah dan lingkungan serta menyediakan sarana dan prasarana yang mendukung kelestarian lingkungan. Konsep rumah yang digunakan adalah eco-housing dengan desain rumah tradisional Sunda, yaitu rumah panggung, sehingga dapat terhindar dari banjir dan tersedia ruang terbuka yang berfungsi sebagai daerah resapan air. Di sepanjang tepi sungai Cimanuk dibuat turap yang berfungsi sebagai pembatas antara sungai dengan permukiman dan sebagai penahan air sungai yang meluap.

Sarana dan prasarana yang diterapkan guna meningkatkan kualitas dan kuantitas air, kualitas tanah, serta kualitas udara di DAS Cimanuk hulu adalah dengan menerapkan ecosanitation, yaitu teknologi air bersih, sanitasi, dan persampahan. Selain itu, dibuat juga jalan lingkungan sebagai fasilitas bagi masyarakat. Aktifitas masyarakat yang kurang menyadari pentingnya kelestarian lingkungan serta tidak adanya pengelolaan sampah dan limbah domestik yang baik menjadi penyebab utama timbulnya bencana serta meningkatnya pencemaran air. Berikut ini merupakan hasil uji kualitas air di lokasi penelitian yang bersumber dari enam titik, yaitu mata air, air mandi cuci, dan air sumur yang berada di RT. 09, serta air MCK mesjid, air sungai, dan air sumur yang berada di RT. 05 . 
Tabel 1. Hasil Uji Kualitas Air RT. 09 dan RT. 05

\begin{tabular}{|c|c|c|c|c|c|c|c|c|c|}
\hline \multirow[b]{2}{*}{ No. } & \multirow[b]{2}{*}{ Parameter } & \multirow[b]{2}{*}{$\begin{array}{l}\text { Satu } \\
\text { an }\end{array}$} & \multirow[b]{2}{*}{$\begin{array}{l}\text { Baku } \\
\text { Mutu }\end{array}$} & \multicolumn{3}{|c|}{ RT. 09} & \multicolumn{3}{|c|}{ RT. 05} \\
\hline & & & & $\begin{array}{c}\text { Mata } \\
\text { air }\end{array}$ & $\begin{array}{c}\text { Air } \\
\text { Mandi } \\
\text { Cuci }\end{array}$ & $\begin{array}{l}\text { Air } \\
\text { Sumur }\end{array}$ & $\begin{array}{r}\text { MCK } \\
\text { Mesjid }\end{array}$ & $\begin{array}{c}\text { Air } \\
\text { Sumur }\end{array}$ & $\begin{array}{c}\text { Air } \\
\text { Sungai }\end{array}$ \\
\hline 1 & TDS & $\mathrm{mg} / \mathrm{L}$ & 1000 & $\begin{array}{c}100 . \\
8\end{array}$ & 69 & 104 & 87 & 110 & 76 \\
\hline 2 & Temperatur & ${ }^{0} \mathrm{C}$ & $\begin{array}{l}\text { Devi } \\
\text { asi } 3\end{array}$ & 25.8 & 25 & 25 & 25 & 25 & 25 \\
\hline 3 & Warna & $\mathrm{TCU}$ & & 5 & 5 & 5 & 5 & 5 & 10 \\
\hline 4 & Kekeruhan & NTU & & 0.27 & 8.94 & 2.45 & 1.1 & 0.44 & 9.61 \\
\hline 5 & Kesadahan & & & $\begin{array}{c}52.1 \\
6\end{array}$ & 36.1 & 64.19 & 42.13 & 54.16 & 36.1 \\
\hline 6 & Besi $(\mathrm{Fe})$ & $\mathrm{mg} / \mathrm{L}$ & 0.3 & $\begin{array}{c}0.06 \\
7\end{array}$ & 1.37 & 0.15 & 0.22 & 0.046 & 1.47 \\
\hline 7 & Mangan (Mn) & $\mathrm{mg} / \mathrm{L}$ & 0.1 & 0.26 & $<0.05$ & $<0.05$ & 0.408 & $<0.05$ & 0.163 \\
\hline 8 & Klorida $\left(\mathrm{Cl}^{-}\right)$ & & 600 & 8.82 & 6.47 & 19.99 & 19.4 & 9.99 & 7.64 \\
\hline 9 & Nitrat $\left(\mathrm{NO}_{3}^{-}\right)$ & $\mathrm{mg} / \mathrm{L}$ & 10 & 8.33 & 8.82 & 5.08 & 3.36 & 10.02 & 6.77 \\
\hline 10 & Nitrit $\left(\mathrm{NO}_{2}^{-}\right)$ & $\mathrm{mg} / \mathrm{L}$ & 0.06 & $\begin{array}{c}0.02 \\
6\end{array}$ & 0.278 & 0.019 & 0.016 & 0.023 & 0.324 \\
\hline 11 & $\begin{array}{l}\text { Ammonium } \\
\left(\mathrm{NH}_{3}\right)\end{array}$ & $\mathrm{mg} / \mathrm{L}$ & 0.5 & $\begin{array}{c}0.03 \\
4 \\
\end{array}$ & 0.151 & 0.044 & 0.051 & $<0.005$ & 0.237 \\
\hline 12 & $\mathrm{pH}$ & & $6-9$ & 6.19 & 7.48 & 6.6 & 6.4 & 6.05 & 6.85 \\
\hline 13 & Sulfat $\left(\mathrm{SO}_{4}\right)$ & $\mathrm{mg} / \mathrm{L}$ & 400 & 4.03 & 2.66 & 4.49 & 4.96 & 9.45 & 3.57 \\
\hline 14 & BOD & $\mathrm{mg} / \mathrm{L}$ & 2 & 6 & 15 & 6 & 9 & 5 & 14 \\
\hline 15 & COD & $\mathrm{mg} / \mathrm{L}$ & 10 & 9.62 & 24.04 & 9.62 & 14.42 & 9.62 & 24.04 \\
\hline 16 & Air Raksa (Hg) & $\mathrm{ppb}$ & 1 & $\begin{array}{c}<0.0 \\
6\end{array}$ & 0.19 & $<0.06$ & $<0.06$ & 0.13 & $<0.06$ \\
\hline 17 & Coli & & & $\begin{array}{c}\text { Tida } \\
\mathrm{k} \\
\text { Baik }\end{array}$ & $\begin{array}{l}\text { Tidak } \\
\text { Baik }\end{array}$ & $\begin{array}{l}\text { Tidak } \\
\text { Baik }\end{array}$ & $\begin{array}{l}\text { Tidak } \\
\text { Baik }\end{array}$ & $\begin{array}{l}\text { Tidak } \\
\text { Baik }\end{array}$ & $\begin{array}{l}\text { Tidak } \\
\text { Baik }\end{array}$ \\
\hline
\end{tabular}

(Sumber: Hasil Uji Laboratorium Institut Teknologi Bandung, 2009)

Berdasarkan hasil uji pada Tabel 1, dapat disimpulkan bahwa kualitas air di lokasi penelitian dalam kondisi yang tidak baik, terutama dilihat dari nilai Biological Oxygen Demand (BOD) dan tes e-coli yang mana seluruh sampel yang jauh melebihi baku mutu. Mengatasi hal tersebut, maka pada tahun 2010 dilakukan penerapan skala penuh eco-sanitation yang diwujudkan melalui pembuatan 2 unit Saringan Pasir Lambat
(SPL) yang ditempatkan di setiap RT, 4 unit MCK komunal yang dilengkapi dengan instalasi pengolahan limbah, serta 2 unit komposter komunal dan tempat pembuangan sampah sementara (TPS). Saringan Pasir Lambat (SPL) merupakan suatu bak penampung berukuran $5 \mathrm{mx} 2$ $\mathrm{m} \times 2 \mathrm{~m}$ yang dilengkapi dengan saringan dan menggunakan sistem aerasi. Sistem aerasi merupakan suatu sistem yang bertujuan untuk meningkatkan

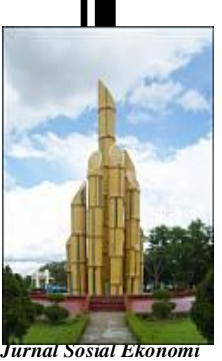

Pertanian, Volume 1, Nomor 1, April 2012, hlm 52-64 


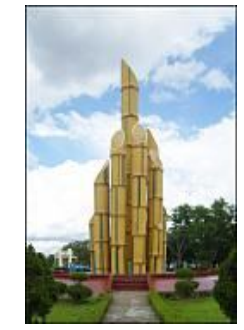

Ma'mun dan Ezmira, Eksternalitas Model Eco settlements di DAS...)

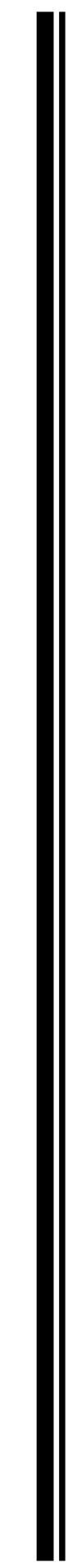

konsentrasi oksigen di dalam air sungai, sehingga senyawa kimia dapat teroksidasi dan juga dapat menghilangkan bau. Air yang tertampung di SPL kemudian dialirkan ke MCK komunal. MCK komunal ditempatkan di lahan hibah milik masyarakat, sehingga menimbulkan rasa tanggung jawab masyarakat dalam pengelolaannya. Setiap RT memiliki 2 unit MCK komunal yang dilengkapi dengan instalasi pengolahan limbah. Instalasi pengolahan limbah terdiri dari kolam sanita dan biogas.

Instalasi pengolahan limbah berfungsi untuk menekan tingkat pencemaran sungai dari limbah domestik. Limbah padat dari MCK disalurkan ke penampungan biogas, sedangkan limbah ternak dibawa langsung ke penampungan biogas. Hasil dari pengolahan limbah padat digunakan sebagai sumber listrik, bahan bakar untuk memasak, dan juga sebagai pupuk tanaman. Sejauh ini, baru sebagian masyarakat di RT. 05 yang sudah memanfaatkan teknologi biogas, sedangkan masyarakat di RT. 09 belum ada yang memanfaatkannya karena teknologi yang digunakan dianggap sulit untuk dioperasikan. Dalam pemanfaatannya, biogas mampu menghasilkan listrik untuk sumber penerangan MCK dan gas untuk memasak selama dua jam.

Selain limbah padat, terdapat juga limbah cair berupa air sabun atau detergen. Limbah cair dari MCK disalurkan ke kolam sanita, dimana dalam kolam sanita tersebut terdapat tanaman dan pada bagian dasarnya diberi batu kapur, kerikil, dan pasir yang berfungsi sebagai penyaring agar air yang dibuang ke kolam ikan dan sungai terbebas dari pencemaran. Sebagai upaya untuk meminimalisir jumlah sampah yang dibuang ke sungai, maka dibuat komposter komunal dan tempat pembuangan sampah sementara (TPS) sebanyak 1 unit di setiap RT dan ditempatkan di samping MCK. Komposter dibagi menjadi tiga bagian, yaitu untuk sampah organik, sampah non-organik, dan sampah yang mengandung bahan kimia. Sampah organik yang terkumpul dan membusuk kemudian digunakan sebagai pupuk organik. Tidak adanya TPA di sekitar lokasi menyebabkan sampah non-organik dan sampah yang mengandung bahan kimia masih dimusnahkan dengan cara dibakar. 


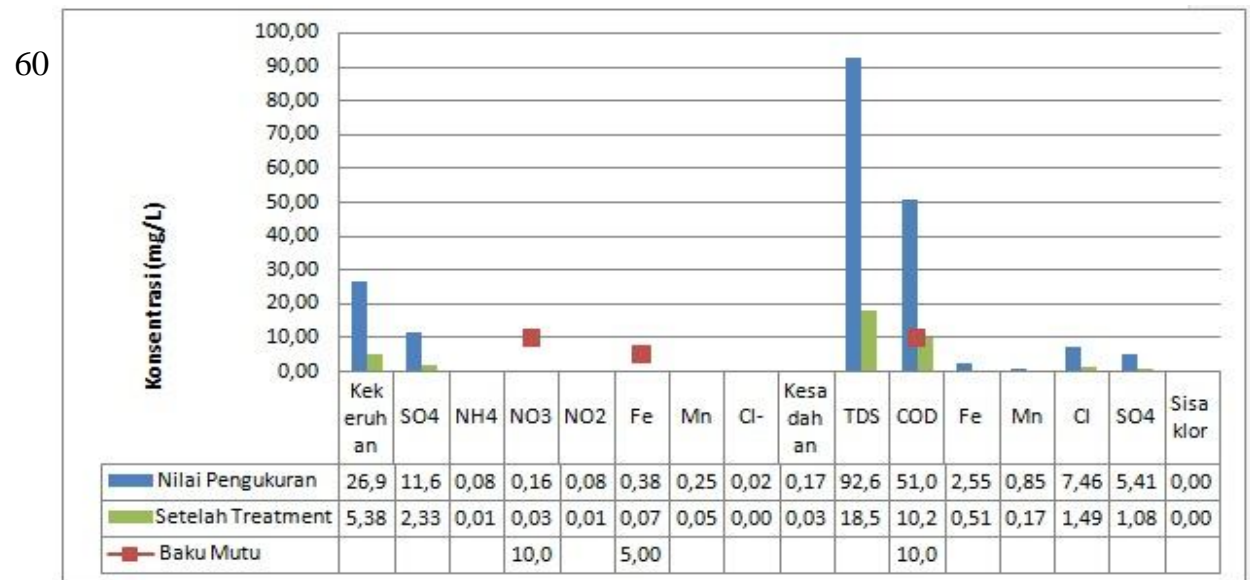

Setelah penerapan skala penuh teknologi eco-sanitation dan persampahan pada tahun 2010, dilakukan pengujian terhadap kualitas air di lokasi penelitian untuk melihat tingkat keberhasilannya. Pengujian dilakukan pada dua musim, yaitu musim kemarau dan musim hujan. Grafik 1 menggambarkan hasil pengujian kualitas air pada musim kemarau, sedangkan pengujian kualitas air musim hujan disajikan pada Grafik.

Grafik 1. Hasil Pengukuran Kualitas Air pada Musim Kemarau Tahun 2009,Baku Mutu, dan Prediksi Setelah Treatment Teknologi

(Sumber: Hasil Pengukuran dan Analisis Puslitbangkim, 2010)

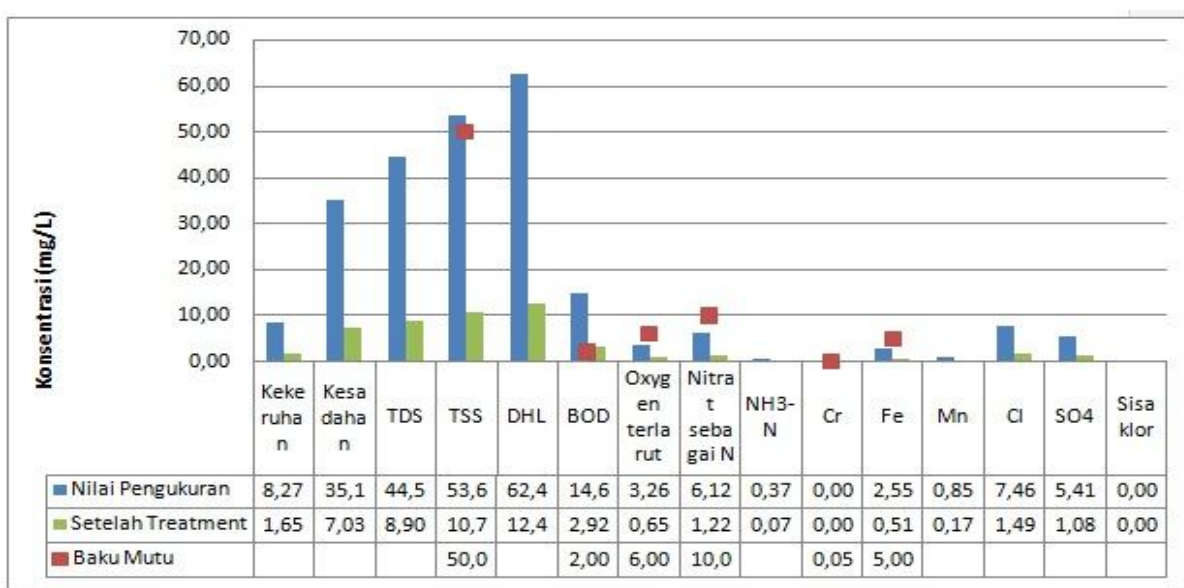

Grafik 2. Hasil Pengukuran Kualitas Air pada Musim Hujan Tahun 2010 Baku Mutu, dan Prediksi Setelah Treatment Teknologi

(Sumber: Hasil Pengukuran dan Analisis Puslitbangkim, 2010)

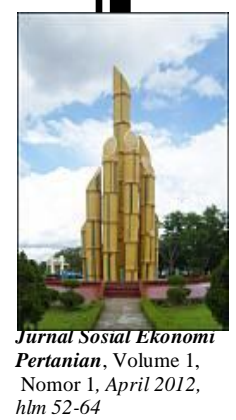




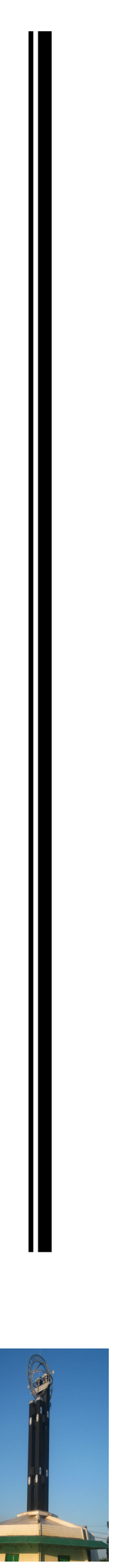

$\begin{array}{lr}\text { Pada Grafik 1, } & \text { dapat } \\ \text { dilihat bahwa } & \text { secara } \\ \text { keseluruhan } & \text { terjadi } \\ \text { peningkatan kualitas air setelah } \\ \text { dilakukan } & \text { treatment. }\end{array}$

Peningkatan kualitas terutama ditunjukkan dengan penurunan kandungan nitrat $\left(\mathrm{NO}_{3}\right)$, besi $(\mathrm{Fe})$, dan Chemical Oxygen Demand (COD) yang berada di bawah nilai baku mutu. Dari hasil pengukuran pada musim hujan tahun 2010 (Grafik 2), beberapa parameter melebihi baku mutu yang disyaratkan berdasarkan untuk kualitas air. Nilai BOD yang melebihi baku mutu menunjukkan bahwa air Sungai Cimanuk sudah terkontaminasi oleh air limbah, terutama air limbah domestik sehingga tidak layak untuk digunakan oleh masyarakat. Adanya treatment ecosanitation mampu mengurangi zat-zat sumber pencemaran sehingga berada di bawah nilai baku mutu dan air layak untuk digunakan oleh masyarakat.

Selain pengujian terhadap kualitas air, dilakukan juga penghitungan Eco-degree (E) sebagai penilaian kategorisasi tingkat ecosettlements di permukiman DAS hulu Cimanuk tepatnya Kampung Muara. Penilaian dilakukan pada saat sebelum dilakukan penerapan skala penuh dan setelah penerapan skala penuh penataan permukiman selama tahun 2010. Berdasarkan penelitian yang dilakukan tim pelaksana Puslitbangkim, diperoleh hasil bahwa nilai $\mathrm{E}$ sebelum dilakukan penerapan skala penuh, tepatnya pada tahun 2009 adalah 43,4. Hal itu menggambarkan bahwa kawasan permukiman di hulu DAS Cimanuk berada pada skala $0<\mathrm{E} \leq 50$, yaitu tidak eco-settlements yang berarti bahwa permukiman tersebut belum dapat menjaga kelestarian hulu DAS dan juga belum ada dukungan sosial serta ekonomi dalam pengelolaaannya.

$\begin{array}{lrr}\text { Setelah } & \text { dilakukan } \\ \text { penerapan } & \text { skala } & \text { penuh, } \\ \text { dilakukan } & \text { penilaian } & \text { kembali } \\ \text { dan hasilnya } & \text { nilai E } & \text { meningkat } \\ \text { menjadi } & 62,6 & \text { yang }\end{array}$
menggambarkan kawasan tersebut berada pada skala $51 \leq$ $\mathrm{E} \leq 75$, yaitu semi ecosettlements. Semi ecosettlements berarti bahwa dalam pengelolaan DAS hulu Cimanuk, permukiman sudah mampu menjaga kelestarian hulu DAS walaupun belum optimal. Kemampuan ini didukung dengan peningkatan kemampuan masyarakan dalam memelihara teknologi yang diterapkan guna meningkatkan kualitas lingkungan.

Berdasarkan hasil penghitungan nilai Eco-degree (E) di Kampung Muara yang menggambarkan bahwa kawasan tersebut termasuk semi eco-settlements, dapat disimpulkan bahwa untuk mencapai kategori ecosettlements diperlukan peningkatan implementasi terhadap beberapa variabel. Salah satu variabel penting yang memiliki koefisien terbesar dalam persamaan 
model adalah tutupan vegetasi. Oleh karena itu, diperlukan upaya dalam meningkatkan kualitas lingkungan yang berazaskan keberlanjutan, salah satunya usahatani konservasi agroforestri.

Sesuai dengan persamaan model eco-settlements, tutupan vegetasi perlu menjadi basis dalam implementasi. Maka dari itu, pada tahun 2012 akan dilaksanakan usahatani konservasi agroforestri. Selain dapat memberikan pendapatan bagi masyarakat setempat, agroforestri dipilih karena tanaman tahunan mampu menjadi media untuk menangkap air hujan dalam jumlah yang besar. Melalui agroforestri, kawasan hulu DAS dapat berfungsi sebagaimana mestinya dan memberikan penghasilan bagi masyarakat khususnya yang turut serta dalam usahatani.

Agroforestri merupakan pola penanaman tumpang sari yang memadukan tanaman tahunan dengan tanaman semusim. Sesuai dengan kondisi iklim, topografi, dan lokasi lahan, maka komoditas yang dipilih adalah tomat (Solanum lycopersicum L.), cabai rawit (Capsicum frutescens L.), kopi (Coffea arabica L.), juga ekaliptus (Eucalyptus urophylla S. T. Blake atau Eucalyptus platyphylla F. Muell.). Pemilihan komoditas tersebut disesuaikan dengan usahatani yang biasa dibudidayakan oleh masyarakat sekitar.

\begin{abstract}
Pola tanam yang digunakan pada sistem agroforestri ini terdiri dari sembilan pola, yaitu pola tanam A (ekaliptus), pola tanam B (tomat), pola tanam C (kopi), pola tanam D (cabai rawit), pola tanam E (ekaliptus, tomat, dan kopi), pola tanam $\mathrm{F}$ (kopi dan ekaliptus), pola tanam G (kopi, tomat, dan cabai rawit), pola tanam $\mathrm{H}$ (tomat dan kopi), dan pola tanam I (ekaliptus, tomat, dan cabai rawit). Pembuatan pola tanam yang berbeda-beda dimaksudkan untuk melihat pola tanam yang mampu megurangi erosi tanah di lokasi penelitian. Pengukuran tingkat erosi akan dilakukan dengan pengambilan sampel pada bak penampung yang ada di setiap sisi lahan.
\end{abstract}

\section{Pilar Ekonomi}

Aspek ekonomi dalam model eco-settlements merupakan pilar penting sebagai penunjang dalam pengembangan DAS hulu. Setiap teknologi yang diterapkan guna meningkatkan kualitas lingkungan membutuhkan biaya yang cukup tinggi. Biaya-biaya yang dikeluarkan untuk mengembangkan DAS hulu di Kampung Muara dan mengacu pada model eco-settlements adalah sebagai berikut:
1. Biaya pemberdayaan masyarakat sebesar Rp82.110.000,00.

2. Biaya pembangunan ecohousing sebesar Rp116.154.224,58.

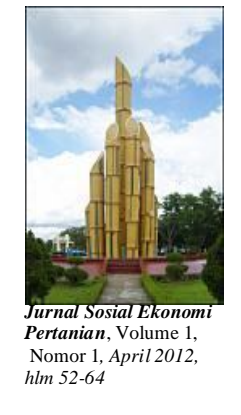




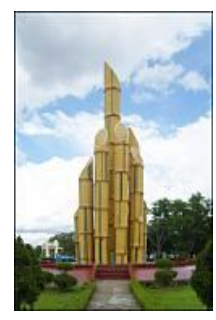

Maswadi, Dampak Penerapan Pungutan Ekspor Crude Palm Oil..

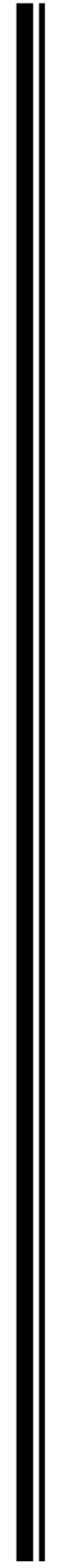

3. Biaya pembangunan ecosanitation dan pengolahan limbah komunal sebesar Rp79.500.000,00.

4. Biaya pembuatan jalan lingkungan sebesar Rp147.756.434,88.

5. Biaya pembuatan turap sebesar Rp63.064.482,17.

6. Biaya pengembangan usahatani konservasi agroforestri yang dianggarkan sebesar Rp32.372.687,50 untuk empat tahun.

Berdasarkan perincian tersebut, maka dapat dihitung total biaya yang dikeluarkan pemerintah melalui Puslitbangkim untuk pengembangan DAS hulu Cimanuk sebesar Rp520.957.829,10. Dilihat dari aspek ekonomi, keterlibatan masyarakat dalam proses pembangunan fisik ditujukan untuk meningkatkan pendapatan melalui upah yang diperoleh, yaitu sebesar Rp45.000,00 per hari. Selain itu, peningkatan pendapatan masyarakat juga akan diperoleh melalui pengembangan usahatani konservasi agroforestri. Melalui agroforestri, petani yang juga masyarakat sekitar akan memperoleh upah sebesar Rp25.000,00 per hari. Upah tersebut akan lebih besar nilainya apabila petani tidak hanya bercocok tanam, tapi juga turut membantu dalam pengukuran tingkat erosi tanah.

Eksternalitas Model Ecosettlements
Pengelolaan hulu DAS Cimanuk melalui model ecosettlements dapat memberikan eksternalitas positif (External Economy) dan menimbulkan eksternalitas negatif (External Diseconomy). Eksternalitas positif yang dihasilkan yaitu berupa tangible benefit (manfaat yang terukur) dan intangible benefit (manfaat yang tidak terukur). Tangible benefit yang diterima masyarakat adalah peningkatan kualitas air yang sesuai dengan standar baku mutu sehingga layak digunakan sebagai air baku. Air bersih sebagai hasil dari penyaringan air sungai akan terus tersedia selama teknologi yang digunakan dirawat secara mandiri dan kontinyu oleh masyarakat. Selain itu, masyarakat juga mendapatkan tambahan pendapatan yang diperoleh dari penjualan bahan-bahan sumber daya lokal, upah pembangunan, dan upah agroforestri.

Berkaca dari kasus pembangunan Waduk Saguling dan Waduk Cirata yang telah dibahas pada penelitian terdahulu, maka eksternalitas positif yang akan diterima oleh masyarakat di bagian tengah dan hilir DAS adalah adanya peningkatan produktivitas pada usahatani. Usahatani yang dimaksud misalnya budidaya perikanan yang secara langsung memanfaatkan air dari Sungai Cimanuk. Adanya peningkatan kualitas air di hulu DAS Cimanuk berarti kualitas air yang sampai ke bagian 
tengah dan hilir pun meningkat dari kondisi sebelumnya. Peningkatan produktivitas tersebut secara linier akan meningkatkan pendapatan peternak ikan.

Intangible benefit yang diperoleh dari implementasi model eco-settlements adalah adanya kontrol terhadap erosi dan penurunan resiko banjir di DAS dari pengembangan usahatani konservasi agroforestri. Penerapan teknologi eco-sanitaton mampu menekan tingkat pencemaran, khususnya di badan Sungai Cimanuk. Intangible benefit yang diperoleh dari aspek sosial adalah terbentuknya lembaga informal Pokjamas Hikmatul Jama'ah dan adanya peningkatan pengetahuan dari proses pelatihan, khususnya dalam pengoperasian teknologi.

Eksternalitas negatif dari implementasi model ini adalah timbulnya ketergantungan masyarakat terhadap bantuan dari pemerintah. Ketergantungan tersebut terlihat dari adanya permintaan masyarakat untuk penambahan jumlah rumah yang direnovasi menjadi eco-housing. Selain itu, adanya hibah lahan yang digunakan untuk pembagunan sarana dan prasarana secara tidak langsung menimbulkan pelimpahan tanggung jawab dalam hal pengelolaannya kepada pihak pemberi hibah atau pengurus Pokjamas saja, padahal seharusnya pengelolaan dilakukan secara bergantian oleh seluruh masyarakat yang turut memanfaatkan sarana dan prasarana tersebut.

\section{KESIMPULAN SARAN}

\section{Kesimpulan}

Eksternalitas positif berupa tangible benefit yang diberikan dari implementasi model eco-settlements adalah peningkatan kualitas air yang sesuai dengan standar baku mutu sehingga layak digunakan sebagai air baku dan tambahan pendapatan yang diperoleh dari penjualan bahan-bahan sumber daya lokal, upah pembangunan, dan upah agroforestri. Intangible benefit yang diperoleh adalah kontrol terhadap erosi dan penurunan resiko banjir di DAS, menekan tingkat pencemaran, khususnya di badan Sungai Cimanuk, terbentuknya lembaga informal Pokjamas Hikmatul Jama'ah, dan adanya peningkatan pengetahuan dari proses pelatihan, khususnya dalam pengoperasian teknologi. Eksternalitas negatif dari implementasi model ini adalah timbulnya ketergantungan masyarakat terhadap bantuan dari pemerintah dan pelimpahan tanggung jawab pengelolaan teknologi yang diterapkan kepada pemilik lahan atau pengurus Pokjamas saja.

\section{Saran}

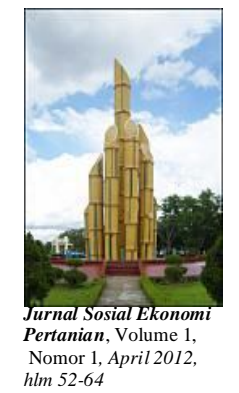




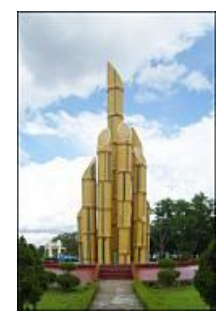

Maswadi, Dampak Penerapan Pungutan Ekspor Crude Palm Oi
Sebagai upaya meminimalisasi eksternalitas negatif yang timbul dari implementasi model ecosettlements, maka diperlukan adanya keberlanjutan pendampingan masyarakat dari tim pelaksana Puslitbangkim secara intensif.

\section{DAFTAR PUSTAKA}

Deviana F., Rani Widyahantari, dan Yulia Hendra. 2010.

Penataan Permukiman di Kawasan Hulu DAS Berbasis Ecosettlements. Pusat Penelitian dan

Pengembangan

Permukiman. . 2011. Kerangka

Model Penilaian EcoDegree Suatu Kawasan Permukiman Hulu Daerah Aliran Sungai. Studi Kasus Hulu DAS Cimanuk-Kampung

Muara, Desa

Sukawargi, Kecamatan Cisurupan, Garut. Pusat Penelitian dan Pengembangan

Permukiman. . 2011. 'Kerangka Model Penilaian EcoDegree Suatu Kawasan Permukiman Hulu Daerah Aliran Sungai." Diskusi Teknis Kerangka Model Penilaian Eco-Degree di Hulu Daerah Aliran Sungai. Bandung: Pusat Penelitian dan Pengembangan Permukiman.

\begin{tabular}{|c|c|c|}
\hline Pusat & Penelitia & dan \\
\hline & Pengembangan & \\
\hline & Permukiman. & 201 \\
\hline & Laporan & \\
\hline & Pengembanga & \\
\hline & Teknologi & Berba \\
\hline & Adaptasi & Perubah: \\
\hline & Iklim. Bandı & ung. \\
\hline
\end{tabular}
11.

. 2011. Laporan Interim. Kegiatan Penyusunan Model Sistem Pengembangan

Teknologi Permukiman

Berbasis Adaptasi

Perubahan Iklim.

Bandung.

Wikarta, E. Kusnadi, Tuhpawana P. S., Yayat Dhahiyat, dan Abdul Rodjak. 2010. Eksternalitas

Pencemaran Sumber Daya Air. Bandung: Unpad Press. Hal: 80. 